\title{
Food aversion learning in kangaroo rats: A specialist-generalist comparison
}

\author{
MARTIN DALY, JOAN RAUSCHENBERGER, and PHIL BEHRENDS \\ McMaster University, Hamilton, Ontario, Canada and University of California, Riverside, California
}

\begin{abstract}
Two species of kangaroo rat (Dipodomys), varying in their degree of dietary specialization, were compared in a series of food aversion learning experiments to test the hypothesis that rapid aversion learning is an adaptation of relatively generalist feeders. The more generalist species indeed learned better or more rapidly in certain experiments, but species differences were at least partly a function of the specific test foods. Interpretation of results is complicated by differences between the two species in their initial reactions to particular foods, in the relative efficacy of different foods in supporting learned aversions, and perhaps even in their physiological responses to illness-inducing and control procedures.
\end{abstract}

In the past decade, many psychologists have embraced the notion that animal learning must be viewed comparatively, with attention being given to the ecological specializations and predispositions of subject species. But despite the popularity of such ideas (e.g., Hinde \& Stevenson-Hinde, 1973; Seligman \& Hager, 1973), there has been surprisingly little explicitly comparative investigation: Few have asked if related animal species that differ in their ecological adaptations respond differently to similar contingencies, and, if so, exactly how.

Food aversion learning has been a favorite paradigm of critics of general accounts of learning because of the striking phenomena of long effective delays of reinforcement (Garcia, Ervin, \& Koelling, 1966) and cue specificity (Garcia \& Koelling, 1966). The animal that has been most studied is the laboratory rat, a species that associates taste cues and subsequent gastric distress with ease. Rozin (1976) in particular has suggested that the rat's capacity for adaptive modification of feeding behavior is the species-specific adaptation of a dietary "generalist," and that "specialists" might be less talented in this sphere.

"Specialist-generalist" is clearly not a dichotomy. It may be treated as a dimension along which species may be ranked according to some index of diversity of foodstuffs consumed. A different definition of specialization focuses upon morphological and behavioral adaptations to particular foodstuffs, but we should expect animals that are specialists by the

This research was supported by NSF Grant BNS77-23665 and NSERC Grant A7026 to M. Daly. We thank MaryAnn Kasprowicz, Jim Kenagy, Bruce Westlund, Margo Wilson, Jacquelyn Yanch, and especially Heather Westlund for help with the work, and Mike Domjan for criticism of the manuscript. Send reprint requests to Martin Daly, Department of Psychology, McMaster University, 1280 Main Street West, Hamilton, Ontario L8S 4K1, Canada. latter criterion to be specialists by the former as well. A clear case of a dietary specialization by either criterion is provided by the chisel-toothed kangaroo rat, Dipodomys microps, in the Owens Valley of California. Most Dipodomys species are predominantly granivorous, consuming seeds of a variety of plant species, but greens are a substantial dietary element in certain seasons. Owens Valley $D$. microps, by contrast, feeds almost exclusively upon the salty, succulent leaves of chenopod plants, mainly shadscale (Atriplex confertifolia), a diet for which it exhibits behavioral and morphological specializations (Kenagy, 1972, 1973). Cheek pouch and stomach content analyses confirm that $D$. microps takes a less diverse diet than other Dipodomys, particularly $D$. merriami, a sympatric species of more typical food habits (e.g., Bradley \& Mauer, 1971; Csuti, 1979; Johnson, 1961; Kenagy, 1973).

These kangaroo rats are therefore appropriate subjects for testing Rozin's (1976) hypothesis of the relevance of the specialist-generalist dimension to aversion learning ability. Within a single genus of rodents of similar gross body structure, we have species with radically different feeding niches and degrees of dietary specialization. Yet both $D$. merriami and $D$. microps can be maintained under identical laboratory conditions on the same mixed diet of seeds and grains. One complication in adapting laboratory paradigms of aversion learning for kangaroo rats is that these animals do not generally drink. In the studies that follow, we have therefore investigated acquisition of aversions to novel solid foods associated with lithium chloride-induced illness.

\section{EXPERIMENT 1}

\author{
Method \\ Subjects and Maintenance. The subjects were 20 adult male \\ kangaroo rats, $10 \mathrm{D}$. merriami and $10 \mathrm{D}$. microps, captured in
}


shadscale scrub in the vicinity of Big Pine, Inyo County, California, and maintained in the laboratory for 57 to 88 days prior to the experiment. The animals were housed individually in $25 \times 46$ $\times 21 \mathrm{~cm}$ clear plastic cages, which were filled to a depth of about $2 \mathrm{~cm}$ with sand, and provided with a tin can for a nest site. Provisions were ad-lib hulled raw wheat, water, and frequent supplements (at least three times weekly) of fresh green vegetables. Lights were turned off at $1200 \mathrm{~h}$ and on at $2400 \mathrm{~h}$.

Half the subjects of each species were randomly assigned to the experimental illness $(\mathrm{LiCl})$ group and half to the control $(\mathrm{NaCl})$ group. There were thus 4 groups ( 2 species $\times 2$ conditions) of five subjects each.

Apparatus. For the experiment, each subject was transferred to a $25 \times 46 \times 21 \mathrm{~cm}$ clear plastic home cage, which was connected by a tunnel $20 \mathrm{~cm}$ long and $6 \mathrm{~cm}$ in diameter to a $15 \times 15 \times 15 \mathrm{~cm}$ plastic box, the "seed box." A sliding door permitted the experimenter to close the tunnel and deny the subject access to the seed box. Home cages contained sand, a tin can, and a water bottle.

Procedure. For the first 5 days after subjects had been placed in the experimental apparatus, baseline ingestion data were collected as follows. Subjects were weighed at $1000 \mathrm{~h}$ and transferred to plastic holding cages for about $1 / 2 \mathrm{~h}$, during which time the wheat remaining in the seed box was removed and weighed and the home cage sand was sifted and all wheat there ("hoarded" wheat) was removed and weighed. Thirty grams of fresh wheat were replaced in the seed box, with the door left closed, and the subject was returned to its home cage. At $1400 \mathrm{~h}$, the seed box doors were opened, which allowed subjects $20 \mathrm{~h}$ free access to the food.

Day 6 was the experimental treatment day. The usual routine was followed, except that, instead of wheat, $20 \mathrm{~g}$ of shelled sunflower seeds, a food the animals had never before encountered, were placed in the seed box. At $1600 \mathrm{~h}$, after $2 \mathrm{~h}$ of access to the food, the seed box doors were closed. Subjects were then removed, injected intraperitoneally with either $.15 \mathrm{M} \mathrm{LiCl}$ or $.15 \mathrm{M} \mathrm{NaCl}$ in a dose of $2 \mathrm{ml} / \mathrm{kg}$ of body weight, and returned to their home cages after the sand was sifted and food was removed. Doors remained shut until the following morning.

On Day $7,30 \mathrm{~g}$ of wheat was placed in the seed box, and the doors were opened at $1000 \mathrm{~h}$ (after $18 \mathrm{~h}$ of deprivation), which allowed access for $24 \mathrm{~h}$. On Test Day 8 , the routine was identical to that on Baseline Days 1 to 5 , except that the food was $20 \mathrm{~g}$ of sunflower seeds. On Day 9, the choice test day, the same routine was again followed, except that food was $10 \mathrm{~g}$ of wheat and $10 \mathrm{~g} \mathrm{of}$ sunflower seeds. After $20 \mathrm{~h}$ of access to the food, the amounts left and hoarded were again measured and the experiment was terminated. A criterion of "aversion" was arbitrarily set at ingestion of $.2 \mathrm{~g}$ or less in $23 \mathrm{~h}$; the subjects that ate more than $.2 \mathrm{~g}$ almost invariably ate more than $.5 \mathrm{~g}$.

Analyses of variance [ $2 \times 2$ (species $\times$ condition)] and planned comparisons of condition effects within species were conducted on the following measures: quantities ingested on treatment day and test day, relative to pretreatment baseline ingestion, and choice test preference (percentage wheat consumed).

\section{Results and Discussion}

One $D$. microps control subject refused food after the $\mathrm{NaCl}$ injection, rapidly lost weight, and died. Its data were eliminated, leaving 19 subjects.

The results supported Rozin's (1976) hypothesis: only D. merriami (the "generalist") learned the aversion (Table 1). Within $D$. merriami, the $\mathrm{NaCl}$ group ate more sunflower seeds than the $\mathrm{LiCl}$ group on Test Day $8[t(8)=4.38, p<.01]$ and exhibited a lesser preference for wheat on Choice Test Day $9[\mathrm{t}(8)=$ $3.29, \mathrm{p}<.01]$. In addition, there was a species $x$ condition interaction in the choice test preference $[F(1,15)=16.64, p<.01]$. It was disconcerting, however, that the interaction was due as much to a reverse condition difference in $D$. microps as to the predicted effect in $D$. merriami (see Day 9 in Table 1 ). A replication seemed in order, and therefore Experiment 2 was conducted.

The two species also differed in their initial reactions to the novel sunflower seeds on Day 6 (Table 1): D. microps was much less reluctant to sample the novel food than was $D$. merriami $[\mathrm{F}(1,15)=4.69$, $\mathrm{p}<.05]$. This result and a similar main effect in the choice test, in which $D$. microps ate a larger proportion of sunflower seeds than did $D$. merriami $[F(1,15)=5.04, p<.05]$, suggest that there may be confounding influences of species differences in the palatability of the foods used; this problem is addressed in Experiment 3.

\section{EXPERIMENT 2}

\section{Method}

This was a replication of Experiment 1, but with the following differences: (1) the subjects were $11 \mathrm{D}$. merriami (5 $\mathrm{NaCl}, 6 \mathrm{LiCl})$ and $11 \mathrm{D}$. microps $(6 \mathrm{NaCl}, 5 \mathrm{LiCl})$, which (2) had been maintained in the laboratory for 182 to 230 days from capture until the time of experiment; (3) the subjects had been exposed to a greater variety of foods in the laboratory, including millet, oats, carrots, and different green vegetables, than had the subjects in Experiment 1 (wheat remained the staple food, and no subject had encountered sunflower seeds).

Table 1

Aversion Learning in Wild-Caught Kangaroo Rats, Experiment 1

\begin{tabular}{|c|c|c|c|c|c|c|c|c|}
\hline & \multicolumn{6}{|c|}{ Mean Quantity Ingested (in Grams) } & \multicolumn{2}{|c|}{$\begin{array}{l}\text { Number Exhibiting } \\
\text { Criterion A version }(\leqslant .2 \mathrm{~g}\end{array}$} \\
\hline & Days 1-5 & Day 6 & Day 7 & Day 8 & & Day 9 & Day 8 & Day 9 \\
\hline & \multicolumn{8}{|c|}{ D. merriami } \\
\hline $\mathrm{NaCl}$ & 3.45 & .04 & 6.62 & $1.56^{*}$ & 3.06 & 1.94 & $0 / 5$ & $0 / 5$ \\
\hline \multirow[t]{2}{*}{$\mathrm{LiCl}$} & 3.42 & .08 & 5.28 & $.33^{*}$ & 4.58 & .20 & $3 / 5$ & $4 / 5$ \\
\hline & \multicolumn{8}{|c|}{ D. microps } \\
\hline $\mathrm{NaCl}$ & 4.61 & .63 & 5.00 & 2.33 & 2.25 & .58 & $0 / 4$ & $2 / 4$ \\
\hline $\mathrm{LiCl}$ & 4.29 & .33 & 6.10 & 1.96 & 1.38 & 2.58 & $1 / 5$ & $0 / 5$ \\
\hline
\end{tabular}

Note-Days 1-5 = baseline, Day $6=$ treatment, Day $8=$ test, Day $9=$ choice test. Novel food ingestion scores are italicized.

*Comparisons in which significant aversion learning was demonstrated. 


\section{Results and Discussion}

Neither the significant aversion learning nor the species difference of Experiment 1 was replicated in Experiment 2. Five animals exhibited critical aversion ( $\leqslant .2 \mathrm{~g}$ ingested) on Test Day 8: two $D$. merriami $\mathrm{LiCl}$, two $D$. microps $\mathrm{LiCl}$, and one $D$. merriami $\mathrm{NaCl}$. The same five plus another $D$. merriami $\mathrm{NaCl}$ subject exhibited criterial aversion on Choice Test Day 9. Within-group variability in all measures was much greater than in Experiment 1, and there was only one significant effect of either species or condition upon an ingestion measure; $D$. microps again ate more sunflower seeds than $D$. merriami on both test days, although not on the treatment day.

The high variance in the ingestion measures may have been a result of the more diverse dietary experience of the subjects. One result that was consistent in Experiments 1 and 2 was $D$. merriami's greater preference for the familiar wheat. To test whether this species difference was food-specific or was, instead, a more general neophobia difference, a new variable was added in Experiment 3: which of the two foods was familiar and which novel.

\section{EXPERIMENT 3}

\section{Method}

Subjects. The subjects were $\mathbf{4 4}$ adult male kangaroo rats, $21 \mathrm{D}$. merriami and 23 D.microps, which had been wild-caught at least 60 days before the experiment and which were maintained individually on a diet of ad-lib oats and either wheat or sunflower seeds (the familiar food) plus frequent supplements of fresh greens. Five $D$. microps became ill and refused food during the experiment, leaving the group compositions shown in Table 2.

Procedure. The procedure was similar to that in Experiment 1, but a 2 nd treatment day was added in order to see if aversions might be demonstrable in a larger proportion of subjects given two learning trials. The schedule was as follows: Days 1 to 5-baseline, as in Experiment 1; Day 6-Treatment 1, as in Experiment 1; Days 7 and 8-baseline, as in Days 1 to 5; Day 9-Treatment 2 (Test 1), as on Day 6; Day 10-baseline, as on Day 7; Day 11-test, as on Day 8, Experiment 1; and Day 12-choice test, as on Day 9, Experiment 1 . For those animals reared on wheat, sunflower seeds were the novel food on treatment and test days, whereas those reared on sunflower seeds encountered novel wheat then. The quantity of food available was $20 \mathrm{~g}$ on all days.

\section{Results and Discussion}

Both species proved capable of learning aversions to both foods under the present procedures, even though there were again indications (especially in the choice test behavior of control subjects) that novel sunflower seeds are relatively more palatable to $D$. microps and novel wheat is relatively more palatable to $D$. merriami. Only $D$. merriami exhibited significant aversion learning (to both foods) after a single $\mathrm{LiCl}$ poisoning.

Mean quantities ingested are presented in Table 2. On' Day 9, D. merriami exhibited significant ( $p<.05, t$ test) aversion learning (i.e., the $\mathrm{LiCl}$ group ate less than the $\mathrm{NaCl}$ group) within each food group tested separately. A significant species $\times$ treatment interaction $[F(1,35)=7.49, p<.01)$ on Day 9 confirms better aversion learning by $D$. merriami at this first test. Whereas $D$. merriami exhibited the predicted LiCl effect regardless of which food was involved, $D$. microps accepted novel sunflower seeds and rejected novel wheat regardless of which treatment had been given.

By Test Day 11, this species difference had disappeared. Both species by then exhibited significant aversion learning (i.e., the $\mathrm{LiCl}$ group ate less than the $\mathrm{NaCl}$ group) to both novel foods ( $\mathrm{p}<.05, \mathrm{t}$ test for each of four comparisons). The Choice Test Day 12 results also demonstrated significant $(p<$ $.05)$ aversion learning with each of the four species $x$ novel food combinations.

Table 2

Aversion Learning in Wild-Caught Kangaroo Rats, Experiment 3

\begin{tabular}{|c|c|c|c|c|c|c|c|c|c|c|c|}
\hline & & \multicolumn{8}{|c|}{ Mean Quantity Ingested (in Grams) } & \multicolumn{2}{|c|}{$\begin{array}{l}\text { Number Exhibiting } \\
\text { Criterion Aversion } \\
(\leqslant .2 \mathrm{~g})\end{array}$} \\
\hline & & Days 1-5 & Day 6 & Days 7-8 & Day 9 & Day 10 & Day 11 & \multicolumn{2}{|c|}{ Day 12} & Day 11 & Day 12 \\
\hline & & \multicolumn{10}{|c|}{ D. merriami } \\
\hline $\begin{array}{l}\text { Sunflower } \\
\text { - novel }\end{array}$ & $\begin{array}{l}\mathrm{NaCl} \\
\mathrm{LiCl}\end{array}$ & $\begin{array}{l}3.09 \\
3.49\end{array}$ & $\begin{array}{l}.30 \\
.30\end{array}$ & $\begin{array}{l}3.52 \\
4.14\end{array}$ & $\begin{array}{l}.34^{*} \\
.04^{*}\end{array}$ & $\begin{array}{l}4.18 \\
5.10\end{array}$ & $\begin{array}{c}2.00^{*} \\
.52^{*}\end{array}$ & $\begin{array}{l}1.74 \\
3.88\end{array}$ & $\begin{array}{r}1.30^{*} \\
.02^{*}\end{array}$ & $\begin{array}{l}0 / 5 \\
2 / 5\end{array}$ & $\begin{array}{l}1 / 5 \\
5 / 5\end{array}$ \\
\hline \multirow[t]{2}{*}{ - novel } & $\begin{array}{l}\mathrm{NaCl} \\
\mathrm{LiCl}\end{array}$ & $\begin{array}{l}2.14 \\
2.33\end{array}$ & $\begin{array}{l}.40 \\
.40\end{array}$ & $\begin{array}{l}2.21 \\
2.40\end{array}$ & $\begin{array}{l}.50^{*} \\
.10^{*}\end{array}$ & $\begin{array}{l}3.32 \\
2.70\end{array}$ & $\begin{array}{l}2.62^{*} \\
1.04^{*}\end{array}$ & $\begin{array}{l}2.58 \\
3.04\end{array}$ & $\begin{array}{l}.90^{*} \\
.20^{*}\end{array}$ & $\begin{array}{l}0 / 5 \\
1 / 6\end{array}$ & $\begin{array}{l}0 / 5 \\
4 / 6\end{array}$ \\
\hline & & \multicolumn{10}{|c|}{ D. microps } \\
\hline $\begin{array}{l}\text { Sunflower } \\
\text { - novel }\end{array}$ & $\begin{array}{l}\mathrm{NaCl} \\
\mathrm{LiCl}\end{array}$ & $\begin{array}{l}3.63 \\
3.78\end{array}$ & $\begin{array}{l}.63 \\
.53\end{array}$ & $\begin{array}{l}3.05 \\
4.29\end{array}$ & $\begin{array}{l}.37 \\
.28\end{array}$ & $\begin{array}{l}4.10 \\
4.60\end{array}$ & $\begin{array}{l}1.90^{*} \\
.58^{*}\end{array}$ & $\begin{array}{l}1.73 \\
3.93\end{array}$ & $\begin{array}{r}1.97^{*} \\
.75^{*}\end{array}$ & $\begin{array}{l}0 / 3 \\
2 / 4\end{array}$ & $\begin{array}{l}0 / 3 \\
2 / 4\end{array}$ \\
\hline $\begin{array}{l}\text { Wheat } \\
\text { - novel }\end{array}$ & $\begin{array}{l}\mathrm{NaCl} \\
\mathrm{LiCl}\end{array}$ & $\begin{array}{l}2.55 \\
2.76\end{array}$ & $\begin{array}{l}.25 \\
.30\end{array}$ & $\begin{array}{l}2.58 \\
2.77\end{array}$ & $\begin{array}{l}.03 \\
.00\end{array}$ & $\begin{array}{l}3.40 \\
3.28\end{array}$ & $\begin{array}{l}.98^{*} \\
.06^{*}\end{array}$ & $\begin{array}{l}2.48 \\
1.82\end{array}$ & $\begin{array}{l}.20^{*} \\
.00^{*}\end{array}$ & $\begin{array}{l}2 / 6 \\
4 / 5\end{array}$ & $\begin{array}{l}4 / 6 \\
5 / 5\end{array}$ \\
\hline
\end{tabular}

Note-Days $1.5=$ baseline, Day $6=$ treatment, Day $9=$ Treatment $2 /$ Test 1 , Day $11=$ Test 2, Day $12=$ choice test. Novel food ingestion scores are italicized. "Comparisons in which significant aversion learning was demonstrated. 


\section{EXPERIMENT 4}

Tests of differences in learning ability should ideally be carried out with laboratory-reared subjects, whose early food experience has been controlled and equated. In Experiment 4, such subjects were tested. Efforts in this direction were limited, however, by difficulties encountered in breeding the animals, first $D$. merriami and later $D$. microps.

\section{Method}

Subjects. The subjects were 52 laboratory-born kangaroo rats, $28 \mathrm{D}$. merriami and $24 \mathrm{D}$. microps, that had been weaned and isolated at 25 days of age and were maintained on ad-lib oats and wheat or sunflower seeds (the familiar food) plus green supplements. They were tested in the aversion learning paradigm when they were between 60 and 110 days of age. The experiment was run in eight replications over a 3-year period, when subjects were available. It was begun between Experiments 1 and 2, before the novel food variable was introduced, and the first laboratoryreared litters were therefore all assigned to the original wheatfamiliar, sunflower-novel condition. Litters were split between $\mathrm{LiCL}$ and $\mathrm{NaCl}$ conditions. Later litters were assigned to the wheat-novel condition. Due to a cessation of breeding in the $D$. microps colony, final group compositions were as shown in Table 3.

Procedure. The procedure was identical to that in Experiment 1, with the exception of the reversed roles of the two foods in the wheat-novel condition.

\section{Results and Discussion}

Laboratory-born subjects in Experiment 4 showed more behavioral variance and less clear aversion learning than did the wild-caught subjects in Experiments 1 and 3. However, D. merriami again exhibited significant one-trial aversion learning to sunflower seeds.

The amounts of food ingested are presented in Table 3. On Test Day 8 , none of the 4 species $\times$ novel food groups exhibited significant aversion learning.

On Choice Test Day 9, aversion was significant in the $D$. merriami sunflower-novel subjects $[\mathrm{t}(14)=$ $2.80, \mathrm{p}<.01]$ and approached significance in the
D. microps sunflower-novel subjects $[\mathrm{t}(16)=1.55$, $\mathrm{p}=.08]$.

Unlike in Experiment 3, D. merriami showed no sign whatever of aversion to novel wheat after $\mathrm{LiCl}$ poisoning: all six subjects ate large quantities of wheat in both test sessions. Smaller group sizes in $D$. microps preclude conclusions; aversion learning in the sunflower-novel group approached significance, and two of three wheat-novel $\mathrm{LiCl}$ subjects totally avoided the wheat in tests.

\section{EXPERIMENT 5}

A generalist feeder with an effective poison-testing strategy may be expected to sample foods in small amounts before deciding that they are safe (Chitty, 1954). Such a strategy, furthermore, should enable the animal to identify the food responsible for illness and would best be served, therefore, if only one novel food at a time were sampled. Experiment 5 was undertaken to see whether these two species would sample novel foods as would such a hypothetical poison tester. The subjects were given simultaneous access to three novel foods.

Some of the variance in performance in Experiments 1 to 4 might be explicable by the hypothesis that wheat is a more palatable food to $D$. merriami and sunflower seeds to $D$. microps. The pretest ingestion data in Experiment 5 provided a test of whether there is a species difference in utilization of the two foods when both are familiar and available ad lib.

\section{Method}

Subjects. The subjects were 26 wild-caught male kangaroo rats, $13 \mathrm{D}$. merriami and $13 \mathrm{D}$. microps. None had been subjects in the aversion experiments, and all had been maintained in the laboratory for at least 1 year on a diet of ad-lib grains (wheat, sunflower seeds, oats) and supplemental greens.

Apparatus. The same cages, tunnels, and seed boxes were used as had been used in the previous experiments.

Table 3

Aversion Learning in Laboratory-Born Kangaroo Rats, Experiment 4

\begin{tabular}{|c|c|c|c|c|c|c|c|c|c|}
\hline & & \multicolumn{6}{|c|}{ Mean Quantity Ingested (in Grams) } & \multicolumn{2}{|c|}{$\begin{array}{c}\text { Number Exhibiting } \\
\text { Criterion Aversion } \\
(\leqslant .2 \mathrm{~g}) \\
\end{array}$} \\
\hline & & Days 1.5 & Day 6 & Day 7 & Day 8 & & Day 9 & Day 8 & Day 9 \\
\hline & & \multicolumn{8}{|c|}{ D. merriami } \\
\hline $\begin{array}{l}\text { Sunflower } \\
\text { - novel }\end{array}$ & $\begin{array}{l}\mathrm{NaCl} \\
\mathrm{LiCl}\end{array}$ & $\begin{array}{l}4.75 \\
4.34\end{array}$ & $\begin{array}{l}.21 \\
.11\end{array}$ & $\begin{array}{l}4.64 \\
4.98\end{array}$ & $\begin{array}{r}1.01 \\
.76\end{array}$ & $\begin{array}{l}1.65 \\
3.45\end{array}$ & $\begin{array}{r}1.51^{*} \\
.89^{*}\end{array}$ & $\begin{array}{l}1 / 8 \\
4 / 8\end{array}$ & $\begin{array}{l}0 / 8 \\
3 / 8\end{array}$ \\
\hline \multirow[t]{2}{*}{$\begin{array}{l}\text { Wheat } \\
\text { - novel }\end{array}$} & $\begin{array}{l}\mathrm{NaCl} \\
\mathrm{LiCl}\end{array}$ & $\begin{array}{l}2.27 \\
2.30\end{array}$ & .75 & $\begin{array}{l}2.95 \\
2.90\end{array}$ & $\begin{array}{l}3.17 \\
2.92\end{array}$ & $\begin{array}{l}2.05 \\
1.87\end{array}$ & $\begin{array}{l}1.50 \\
1.15\end{array}$ & $\begin{array}{l}0 / 6 \\
0 / 6\end{array}$ & $\begin{array}{l}0 / 6 \\
0 / 6\end{array}$ \\
\hline & & \multicolumn{8}{|c|}{ D. microps } \\
\hline $\begin{array}{l}\text { Sunflower } \\
\text { - novel }\end{array}$ & $\begin{array}{l}\mathrm{NaCl} \\
\mathrm{LiCl}\end{array}$ & $\begin{array}{l}5.29 \\
5.42\end{array}$ & $\begin{array}{l}.19 \\
.62\end{array}$ & $\begin{array}{l}5.49 \\
5.78\end{array}$ & $\begin{array}{l}1.68 \\
1.12\end{array}$ & $\begin{array}{l}2.47 \\
2.94\end{array}$ & $\begin{array}{l}2.12 \\
1.64\end{array}$ & $\begin{array}{l}1 / 9 \\
2 / 9\end{array}$ & $\begin{array}{l}1 / 9 \\
4 / 9\end{array}$ \\
\hline $\begin{array}{l}\text { Wheat } \\
\text { - novel }\end{array}$ & $\begin{array}{l}\mathrm{NaCl} \\
\mathrm{LiCl}\end{array}$ & $\begin{array}{l}2.67 \\
3.09\end{array}$ & $\begin{array}{l}.03 \\
.10\end{array}$ & $\begin{array}{l}3.33 \\
3.27\end{array}$ & $\begin{array}{r}3.13 \\
.77\end{array}$ & $\begin{array}{l}2.00 \\
1.90\end{array}$ & $\begin{array}{r}2.20 \\
.77\end{array}$ & $\begin{array}{l}1 / 3 \\
2 / 3\end{array}$ & $\begin{array}{l}1 / 3 \\
2 / 3\end{array}$ \\
\hline
\end{tabular}


Procedure. For the first 3 days in the apparatus, subjects were allowed $23 \mathrm{~h}$ of access daily to seed boxes containing $5 \mathrm{~g}$ of wheat and $2.5 \mathrm{~g}$ of sunflower seeds. The doors were opened at $1400 \mathrm{~h}$ and closed at $1300 \mathrm{~h}$. Upon closing the door, the experimenter collected and weighed the food left in the seed box and in the home cage, as in Experiment 1. For the next 3 days, only $2 \mathrm{~h}$ of access (1400 to $1600 \mathrm{~h}$ ) were allowed, to encourage the animals to investigate the seed boxes soon after $1400 \mathrm{~h}$. Any food hoarded was left with the animal until $1300 \mathrm{~h}$ on the following day, so 23 -h ingestion was again determined.

On Day 7, seed boxes contained three novel foods: $3 \mathrm{~g}$ each of barley, lentils, and red lentils. The subjects were observed, and the times of emergence and first contacts with the foods were noted. One, 2, 3, and $4 \mathrm{~h}$ after their first access to the novel foods, the subjects briefly were removed to holding cages while the amounts of each food remaining in the seed boxes and in the home cages were measured. After a 9-min time-out, the subjects were returned to their cages, with the foods still where they had left them. After the fourth hourly check, the subjects were permitted 19 more hours of access to the novel foods. At $1300 \mathrm{~h}$ on Day 8, the experiment was terminated, and the amounts ingested and hoarded were determined.

\section{Results and Discussion}

All the subjects of both species ate both wheat and sunflower seeds during the pretest. The mean daily ingestion was $.95 \mathrm{~g}$ of wheat and $1.25 \mathrm{~g}$ of sunflower seeds for $D$. merriami ( $43 \%$ wheat) and $1.01 \mathrm{~g}$ of wheat and $1.77 \mathrm{~g}$ of sunflower seeds for $D$. microps $(36 \%$ wheat). The species difference in the percentages of wheat did not approach significance $[\mathrm{t}(24)$ $=1.12]$.

Most of the subjects of both species investigated the novel foods with evident interest and ambivalence, dashing back to the home cage and reemerging one or more times before cheek-pouching some food and hoarding it. Several of the subjects of both species hoarded the novel foods one type at a time to separate sites in the home cage, and several hoarded some or all of at least two of the three food types before actually sampling any. Others sampled the novel foods in the seed box before hoarding them. Ten of $13 \mathrm{D}$. microps and 6 of $13 \mathrm{D}$. merriami sampled at least one novel food within the 1st hour of access and $1 D$. microps and $3 D$. merriami not until the 4th hour, by which time all subjects had sampled at least one novel food.

For each subject, we recorded the number of different novel foods sampled during the 1st hour in which any were sampled. Nine $D$. merriami sampled only one focd in the 1st sampling hour, four sampled two, and none sampled all three. In $D$. microps, by contrast, only four sampled one food, four sampled two, and five sampled all three. Thus, $D$. merriami was significantly more inclined than $D$. microps to separate sampling of the foods $(p<.01$, directional hypothesis, Mann-Whitney test). After $23 \mathrm{~h}$, all $D$. microps had sampled all three foods, but six $D$. merriami had still sampled only two. Thus, $D$. merriami, more than $D$. microps, exhibits the sort of food-sampling pattern that was hypothesized to be appropriate for poison testing.

\section{GENERAL DISCUSSION}

Evidence was obtained of better (Experiment 1) or more rapid (Experiment 3) aversion learning by $D$. merriami, the more generalist feeder. The clearest evidence that the two species may differ in aversion learning ability was in Experiment 3, in which $D$. merriami acquired aversions to both test foods in one trial but $D$. microps did so only after two trials. These results support Rozin's (1976) hypothesis. Furthermore, $D$. merriami exhibited a food-sampling pattern apparently better adapted to testing for poisons (Experiment 5).

However, species differences in initial responses to the experimental foods complicate the interpretation of these experiments. If data for the 132 subjects in Experiments 1 to 4 are combined, then a large species difference in food-specific neophobia is apparent: at the first pretreatment exposure to novel sunflower seeds, $D$. microps ate twice as much (mean $=.43 \mathrm{~g}$ ) as did $D$. merriami (mean $=.22 \mathrm{~g}$ ) $[\mathrm{t}(90)=2.05$, $\mathrm{p}<.05$ ]; at the first pretreatment exposure to novel wheat, by contrast, $D$. microps ate much less $(.20 \mathrm{~g})$ than did $D$. merriami $(.68 \mathrm{~g})[\mathrm{t}(38)=2.61, \mathrm{p}<.05]$. Table 4 summarizes aversion learning performance for the 132 subjects in Experiments 1 to 4. The numbers attaining criterial aversion in all tests seem to indicate that only $D$. merriami acquired the aversion to sunflower seeds and only $D$. microps to wheat (although the next column shows that some learning occurred in the other combinations, namely $D$. merriami/wheat-novel and $D$. microps/sunflower-novel, as well). The species differences in food-specific neophobia thus appears to be predictive of the aversion performance, with each species more readily exhibiting acquired aversions to that food of which they were more neophobic before poisoning. However, these differences do not persist as species-typical preferences once the foods are familiar; this fact is

Table 4

Number of Subjects Exhibiting Criterion Aversion by Condition, Experiments 14 Combined

\begin{tabular}{clccr}
\hline & & $\mathrm{N} 1$ & $\mathrm{~N} 2$ & $\mathrm{~N} 3$ \\
\hline Sunflower & $\mathrm{NaCl}$ & 23 & 1 & 5 \\
- novel & $\mathrm{LiCl}$ & 24 & 10 & 15 \\
Wheat & $\mathrm{NaCl}$ & 11 & 0 & 0 \\
- novel & $\mathrm{LiCl}$ & 12 & 1 & 6 \\
& & & D. microps & \\
Sunflower & $\mathrm{NaCl}$ & 22 & 1 & 4 \\
- novel & $\mathrm{LiCl}$ & 23 & 2 & 11 \\
Wheat & $\mathrm{NaCl}$ & 9 & 3 & 7 \\
- novel & $\mathrm{LiCl}$ & 8 & 6 & 7 \\
\hline
\end{tabular}

Note $-N 1=$ number of subjects run; $N 2=$ number exhibiting criterion aversion on all tests; $N 3=$ number exhibiting criterion aversion on any test. The aversion criterion was ingestion of $2 \mathrm{~g}$ or less in a $23 . h$ period. 
shown both by the pretest data in Experiment 5 and by other ad-lib preference tests of 10 days' duration in which six $D$. merriami ate $46 \%$ wheat and $54 \%$ sunflower seeds while six $D$. microps ate $51 \%$ wheat and $49 \%$ sunflower seeds. The interactive effect of food and species upon both neophobia and aversion performance cannot, then, be attributed simply to a species difference in the palatability of the two foods.

A similar change in preference once novel foods become familiar can be seen with the particular novel foods sampled in Experiment 5 . In the first $23 \mathrm{~h}$ of exposure, $13 \mathrm{D}$. merriami took $58 \%$ barley, $32 \%$ lentils, and $10 \%$ red lentils, while the $13 \mathrm{D}$. microps took $41 \%, 25 \%$, and $34 \%$, respectively. These proportional selections differed significantly. When four subjects of each species were familiar with these foods and were given 5-day ad-lib ingestion tests, D. merriami ate $47 \%, 27 \%$, and $26 \%$, respectively, while $D$. microps ate $55 \%, 19 \%$, and $26 \%$, respectively. Thus, the initial species differences, with $D$. merriami preferring barley and being neophobic with respect to red lentils to a greater degree than was $D$. microps, were not predictive of later ingestion. So although the species-typical sampling behavior in Experiment 5 may indeed be dependent upon the particular foods used, this difference, like the aversion differences, cannot be attributed simply to species differences in the palatability of the foods.

That species differences in Experiments 1 and 3 reflect aversion learning ability must furthermore remain only a hypothesis until the possibility of critically different responses to the injections is eliminated. Three D. microps individuals (one in Experiment 1 and two in Experiment 3) refused food and died after the $\mathrm{NaCl}$ "control" injection; others did not seem adversely affected, but the possibility is immediately raised that saline injections may affect the two species differently. Besides the formidable problem of equating doses for two species, there are grounds to suspect different responses to salt loads. Although $D$. microps shaves and discards the hypersaline outer tissue of their natural saltbush leaf diet (Kenagy, 1972), they probably ingest and excrete several times as large a quantity of various salts as do $D$. merriami. However, $D$. merriami has the greater ability to concentrate salts in urine (Kenagy, 1973), presumably because $D$. microps ingests more water in its leafy diet. Not surprisingly, body water turnover is more rapid in D. microps (Mullen, 1971). Finally, $D$. merriami taste receptors are more sensitive to both $\mathrm{NaCl}$ and $\mathrm{LiCl}$ than are those of $D$. microps, whereas the latter species is more sensitive to divalent chloride salts (Harper, Kenagy, \& Oakley, Note 1). These considerations illustrate how difficult it is to attain truly comparable treatments in comparative experiments, and perhaps help explain the absence of explicitly comparative studies in the food aversion literature.
Whether kangaroo rats sample dangerous foods and acquire aversions in nature remains an open question. Novel seeds may be olfactorily classified as food or nonfood without being sampled. One toxic seed found in the Sonora Desert habitats of D. merriami is jojoba (Simmondsia chinensis), which contains potentially lethal cyanogenic glucosides. One heteromyid rodent, Perognathus baileyi, evidently specializes on jojoba, although its method of detoxification is unknown; other heteromyids, including $D$. merriami, are reluctant to sample jojoba even when starving (Sherbrooke, 1976). We offered jojoba seeds to $D$. merriami captured both in areas where the plant occurs and in shadscale scrub several hundred kilometers away, as well as to naive laboratory-reared animals descended from both geographical populations. No $D$. merriami would sample jojoba seed, even after $24 \mathrm{~h}$ of food deprivation, and neither would any $D$. microps, whose natural range does not include jojoba. Thus, at least one naturally occurring toxic seed is rejected by kangaroo rats without being sampled. Conversely, some novel foods seem instantly acceptable; thus, several $D$. merriami immediately ate more than $1 \mathrm{~g}$ of wheat upon first exposure, and most individuals ate more than $.5 \mathrm{~g}$. But although no $D$. microps responded as enthusiastically to novel wheat, the two species eventually incorporated equal amounts of wheat into their diets. In view of such changes between neophobias and later preferences, it seems clear that kangaroo rat food selection is sensitive to experience, and it would be surprising if such experiential effects were not significant in nature. Nevertheless, field studies of foraging by $D$. merriami and other granivorous heteromyids have led most researchers to conclude that animals are selective for microhabitat and/or seed size, but not for seed species (Brown, Reichman, \& Davidson, 1979). This judgment seems to be more a consequence of the hypotheses ecologists have chosen to test (especially hypotheses about resource allocation among competing species) than of a real lack of selectivity. More field study of food selection is needed.

Also deserving of further study is the question of whether or not it is reasonable to expect interspecific variability in aversion learning capabilities over the dimension of dietary specialist-generalist. The Rozin (1976) hypothesis covertly assumes that increasingly effective aversion learning mechanisms are increasingly costly to evolve or maintain. Otherwise, why should not a species like $D$. microps, relatively specialized with respect to a single food species but occasionally exploiting other species, make use of the same effective mechanism as Rattus? Seligman (1970), in contrast to Rozin, has argued that aversion learning should be a primitive and widespread capacity for dealing with a universal problem, namely, food selection. Few mammals are so specialized in 
their diets that they might be expected to eschew experiential information altogether.

\section{REFERENCE NOTE}

1. Harper, K. J., Kenagy, G. J., \& Oakley, G. The gustatory responses of two species of kangaroo rats. Paper presented to the Michigan chapter of the Society for Neuroscience, 1976.

\section{REFERENCES}

Bradley, W. G., \& Mauer, R. A. Reproduction and food habits of Merriam's kangaroo rat, Dipodomys merriami. Journal of Mammalogy, 1971, 52, 497-507.

Brown, J. H., Reichman, O. J., \& Davidson, D. W. Granivory in desert ecosystems. Annual Review of Ecology and Systematics, $1979,10,207-227$.

CHITTY, D. The control of rats and mice. Oxford: Clarendon, 1954.

Csuti, B. A. Patterns of adaptation and variation in the Great Basin kangaroo rat (Dipodomys microps). University of California Publications in Zoology, 1979, 111, viii +69 .

Garcia, J., Ervin, R. R., \& Koelling, R. A. Learning with prolonged delay of reinforcement. Psychonomic Science, 1966, 5, 121-122.

Garcia, J., \& Koelining, R. A. Relation of cue to consequence in avoidance learning. Psychonomic Science, 1966, 4, 123-124.
Hinde, R. A., \& Stevenson-Hinde, J. (Eds.) Constraints on learning: Limitations and predispositions. London: Academic Press, 1973.

Johnson, D. R. The food habits of rodents on rangelands of southern Idaho. Ecology, 1961, 42, 407-410.

KENAGY, G. J. Saltbush leaves: Excision of hypersaline tissue by a kangaroo rat. Science, 1972, 178, 1094-1096.

KenAGY, G. J. Adaptations for leaf-eating in the Great Basin kangaroo rat Dipodomys microps. Oecologia, 1973, 12, 383-412.

Mullen, R. K. Energy metabolism and body water turnover rates of two species of free-living kangaroo rats, Dipodomys merriami and Dipodomys microps. Comparative Biochemistry \& Physiology, 1971, 39A, 379-390.

Rozin, P. The selection of foods by rats, humans and other animals. In J. S. Rosenblatt, R. A. Hinde, E. Shaw, \& C. Beer (Eds.), Advances in the study of behavior (Vol. 6). London: Academic Press, 1976.

Seligman, M. E. P. On the generality of the laws of learning. Psychological Review, 1970, 77, 406-418.

Seligman, M. E. P., \& Hager, J. (Eds.) The biological boundaries of learning. New York: Appleton-Century-Crofts, 1973.

Sherbrooke, W. C. Differential acceptance of toxic jojoba seed (Simmondsia chinensis) by four Sonoran desert heteromyid rodents. Ecology, 1976, 57, 596-602.

(Manuscript received October 23, 1981; revision accepted for publication May 13, 1982.) 